\title{
Anatomical study of the leaves and evaluation of the chemical composition of the volatile oils from Psidium guineense Swartz leaves and fruits
}

\author{
Estudo anatômico das follhas e avaliação da composição química dos óleos voláteis de follhas e frutos
} de Psidium guineense Swartz

Estudio anatómico de las hojas y evaluación de la composición química de los aceites volátiles de hojas y frutos de Psidium guineense Swartz

Fernando Yano Abrao

ORCID: https://orcid.org/0000-0002-0553-0946 Universidade Federal de Goiás, Brazil E-mail: yanobruce@gmail.com

Henrique Marques da Costa

ORCID: https://orcid.org/0000-0002-5035-5518 Universidade Federal de Goiás, Brazil

E-mail: henriquemarques0611@gmail.com

Tatiana de Sousa Fiuza

ORCID: https://orcid.org/0000-0003-0135-177X Universidade Federal de Goiás, Brazil tatianaanatomia@gmail.com

Camila Aline Romano

ORCID: https://orcid.org/0000-0002-3564-6368 Universidade Federal de Goiás, Brazil E-mail: camilaalineromano@gmail.com

Heleno Dias Ferreira

ORCID: https://orcid.org/0000-0001-7763-734X Universidade Federal de Goiás, Brazil E-mail: hdiasicb@gmail.com

Luiz Carlos da Cunha

ORCID: https://orcid.org/0000-0002-1525-8528 Universidade Federal de Goiás, Brazil

E-mail: lucacunha@gmail.com

Jerônimo R. Oliveira Neto

ORCID: https://orcid.org/0000-0002-0261-4554 Universidade Federal de Goiás, Brazil

E-mail: jeronimoneto8@gmail.com

José Realino de Paula

ORCID: https://orcid.org/0000-0002-4424-7692 Universidade Federal de Goiás, Brazil E-mail: jose_realino@ufg.br

\begin{abstract}
Psidium guineense Swartz is a bush used in urinary tract diseases, diarrhea, and dysentery. The present study aims to perform the anatomical study of the leaves and evaluation of the chemical composition of the volatile oils from Psidium guineense Swartz leaves and fruits. The botanical material was collected in Hidrolândia, Goiás. Anatomical characterization and phytochemical screening of the leaves were performed by conventional methods. Leaf and fruit (green fruits, immature fruits, and ripe fruits) powders were submitted to hydrodistillation in the Clevenger apparatus and the identification of the chemical components of the volatile oils obtained was done by GC-MS. The leaf blade is hypoestomatic with paracytic and anisocytic stomata. Secretory cavities are observed in the central vein, mesophyll, petiole, and young stem. The powder moisture content was $7.4 \%$. The total ash content of the leaf powder was $6.3 \%$ and the acid-insoluble ash content was $0.8 \%$. The presence of tannins, flavonoids, and saponins in the leaves were identified. Leaves volatile oil's majority compounds were 2Z,6E-farnesol (23.1-25.4\%), $\alpha$-copaene (17.7-20.3\%), muurola-4,10(1.4) dien-1- $\beta$-ol (5.8-6.7\%), epi- $\alpha$-cadinol (5.5- 6.3\%), and $\delta$-Cadinene (5.0- 5.9\%). Fruits volatile oil's majority compounds were 2Z,6E-farnesol (31.9-41.4\%), $\alpha$-copaene (13.3-26.6\%), $\delta$-cadinene (5.4-9.8\%), $\gamma$ himachalene (3.8-6.1\%), and cubenol (2.6-6.1\%). This is the first report on anatomical study of the leaves, and chemical composition of volatile oils from leaves and fruits of $P$. guineense collected in Hidrolândia, Goiás.
\end{abstract}

Keywords: Cerrado; Essential oils; Medicinal plants; Myrtaceae. 


\begin{abstract}
Resumo
Psidium guineense Swartz é um arbusto usado em doenças do trato urinário, diarréia e disenteria. O presente estudo tem como objetivo realizar o estudo anatômico das folhas e avaliação da composição química dos óleos voláteis das folhas e frutos de Psidium guineense Swartz. O material botânico foi coletado em Hidrolândia, Goiás. A caracterização anatômica e a triagem fitoquímica das folhas foram realizadas por métodos convencionais. Os pós das folhas e frutos (frutos verdes, frutos imaturos e frutos maduros) foram submetidos à hidrodestilação em aparelho de Clevenger e a identificação dos componentes químicos dos óleos voláteis obtidos foi feita por CG-EM. A lâmina foliar é hipoestomática com estômatos paracíticos e anisocíticos. Cavidades secretoras são observadas na nervura principal, mesofilo, pecíolo e caule jovem. O teor de umidade do pó foi de 7,4\%. O teor total de cinzas do pó da folha foi de $6,3 \%$ e o teor de cinzas insolúveis em ácido foi de $0,8 \%$. Foi identificada a presença de taninos, flavonóides e saponinas nas folhas. Os compostos majoritários do óleo volátil das folhas foram $2 \mathrm{Z}$, 6E-farnesol $(23,1-25,4 \%)$ e $\alpha$-copaeno (17,7$20,3 \%$ ), muurola-4,10(14)-dien- $1 \beta$-ol (5,8-6,7\%), epi- $\alpha$-Cadinol $(5,5-6.3 \%)$ e $\delta$-Cadineno (5,0- 5,9\%). Os compostos majoritários de óleo volátil dos frutos foram 2Z,6E-farnesol (31,9-41,4\%), $\alpha$-copaeno $(13,3-26,6 \%), \delta$-cadineno $(5,4-$ $9,8 \%), \gamma$-himachalene $(3,8-6,1 \%)$ e cubenol $(2,6-6,1 \%)$ Este é o primeiro relato de estudo anatômico das folhas e composição química dos óleos voláteis das folhas e frutos de $P$. guineense coletados em Hidrolândia, Goiás.
\end{abstract}

Palavras-chave: Cerrado; Óleos essenciais; Plantas medicinais; Myrtaceae.

\title{
Resumen
}

Psidium guineense Swartz es un arbusto utilizado en enfermedades del tracto urinario, diarrea y disentería. El presente estudio tiene como objetivo realizar el estudio anatómico de las hojas y evaluar la composición química de los aceites volátiles de las hojas y frutos de Psidium guineense Swartz. El material botánico fue recolectado en Hidrolândia, Goiás, la caracterización anatómica y cribado fitoquímico de las hojas se realizó por métodos convencionales. Los polvos de hojas y frutos (frutos verdes, frutos inmaduros y frutos maduros) fueron sometidos a hidrodestilación en aparato Clevenger y la identificación de los componentes químicos de los aceites volátiles obtenidos se realizó mediante CGEM. La lámina de la hoja es hipoestomática con estomas paracíticos y anisocíticos. Se observan cavidades secretoras en la vina principal, mesófilo, pecíolo y tallo joven. El contenido de humedad del polvo fue del 7,4\%. El contenido total de cenizas del polvo de hojas fue del 6,3\% y el contenido de cenizas insolubles en ácido fue del $0,8 \%$. Se identificó la presencia de taninos, flavonoides y saponinas en las hojas. Los compuestos principales en el aceite volátil de las hojas fueron $2 \mathrm{Z}, 6 \mathrm{E}$-farnesol (23,1-25.4\%), $\alpha$-copaeno (17,7-20.3\%), muurola-4,10(14)-dien-1 $\beta$-ol (5,8-6,7\%), epi- $\alpha$-Cadinol $(5,5-6,3 \%)$ y $\delta$-Cadineno (5,0-5,9\%). Los principales compuestos de aceite volátil de frutas fueron $2 \mathrm{Z}$, $6 \mathrm{E}$-farnesol $(31,9-41,4 \%), \alpha$-copaene $(13.3-26.6 \%), \delta$-cadinene $(5.4-9.8 \%), \gamma$-himachalene $(3.8-6.1 \%)$ y cubenol $(2.6-6.1 \%)$. Este es el primer informe de un estudio anatómico de las hojas y composición química de los aceites volátiles de las hojas y frutos de $P$. guineense recolectados en Hidrolândia, Goiás.

Palabras clave: Cerrado; Aceites esenciales; Plantas medicinales; Myrtaceae.

\section{Introduction}

The Cerrado is the most diverse savanna in the world, with 12,700 known vascular plants species, $35 \%$ of which are endemic (Forzza, et al., 2012; Novaes, et al., 2013). The Cerrado has 11 phytophysiognomies, divided into forest, savanna, and peasant formations (Coutinho, 2006). Myrtaceae family with 211 species occur in the Cerrado and are distributed in 14 genera, highlighting Eugenia L., Myrcia DC. Ex. Guill., and Psidium L. (Novaes, et al., 2013).

Psidium guineense Swartz known as "araçá comum", "araçá-azedo", or "araçá-mirim", is distributed in Brazilian States such as Amazonas, Pará, Goiás, Minas Gerais, São Paulo, Mato Grosso, and Ceará (São Paulo, 1978). P. guineense is a shrub of up to $6 \mathrm{~m}$, with yellowish-brown coriaceous leaves of elliptical shape and flat central rib. The flowers can be solitary or in dichásio with white petals (Silva \& Mazine, 2016; Peixoto, et al., 2017). The fruit is a globular berry rich in vitamin C with high dispersion capacity, can be consumed in natura or as an ice cream, beverages, and liquors. The pulp is fleshy, white, mucilaginous, sweet, slightly sour, and aromatic and has numerous small seeds (Manica, 2000).

Brazilian folk medicine uses $P$. guineense to treat urinary tract diseases, diarrhea, and dysentery. Due to its high tannin content, fruit peel can be used in tanneries (Rodrigues \& Carvalho, 2001; González, et al., 2005). P. guineense has volatile oils stored in the leaf and fruit secretory cavities (Oliveira, et al., 2014; Silva, et al., 2020).

Scientific studies performed with $P$. guineense leaves observed neuropharmacological effects in mice as the increase of sleeping time, anticonvulsant action, analgesic action (Santos, et al., 1996; 1997); anti-nociceptive, anxiolytic and antidepressant activity (Santos, et al., 2020). 
The present study aims to perform the anatomical study of the leaves and evaluation of the chemical composition of the volatile oils from Psidium guineense Swartz leaves and fruits collected in Hidrolândia, Goiás.

\section{Material and Methods}

\subsection{Plant material}

Psidium guineense Swartz leaves, green fruits, immature fruits, and ripe fruits were collected in January and February, during the morning and the first day each month in Hidrolândia - GO (786 m, 16 $6^{\circ} 53^{\prime} 59^{\prime}$ ' S and 49 13' 29”' W). Professor Dr. José Realino de Paula identified the specimen, and a voucher was deposited at the UFG Herbarium, Goiás, Brazil, under code number UFG-67843. The leaves and fruits were dried in an oven with air circulation at $38{ }^{\circ} \mathrm{C}$ by 2 days.

\subsection{Anatomical study}

For the anatomical study, leaves and stems were sectioned and stained with Alcian blue/safranin 9: 1 (Kraus \& Arduin, 1997) and histochemical tests Steinmetz and Lugol reagents (Costa, 2001). The photographic recording of the anatomical structures was performed in a photomicroscope (Zeiss-Axiostar plus) with a coupled digital camera (Canon Power Shot G10) using the Axion Vision 4.8 software.

\subsection{Phytochemical screening}

The moisture analyzer (Ohaus model MB35) determined the moisture content leaf powder (Brasil, 2010). Total and insoluble ash content was determined according to the Brazilian Pharmacopoeia (Brasil, 2019). The phytochemical composition of leaf powder was screened for the presence of anthraquinone heterosides, coumarins, steroids, and triterpenes; starch (Lugol), alkaloids, flavonoid heterosides, saponins heterosides, and tannins (Costa, 2001; Cunha, 2009).

\subsection{Volatile oils}

Healthy leaves, green fruits, immature fruits, and ripe fruits were collected from ten different individuals in January and February, triturated immediately before volatile oil extraction, and $90 \mathrm{~g}$ of the powder submitted to hydrodistillation in a Clevenger-type apparatus for $2 \mathrm{~h}$. After drying with anhydrous $\mathrm{Na}_{2} \mathrm{SO}_{4}$, the oils were stored in glass vials at a temperature of $18{ }^{\circ} \mathrm{C}$ until further analysis. Each experiment was performed in triplicate. The composition of the volatile oils was analyzed using a Shimadzu GC/MS-QP5050A fitted with a fused silica SBP-5 (30 $\mathrm{m} \times 0.25 \mathrm{~mm}$ I.D.; $0.25 \mu \mathrm{m}$ film thickness) capillary column (composed of $5 \%$ phenylmethyl polysiloxane). The following temperature program was used: the temperature was raised from $60-240{ }^{\circ} \mathrm{C}$ at a rate of $3{ }^{\circ} \mathrm{C} / \mathrm{min}$ and then to $280{ }^{\circ} \mathrm{C}$ at a rate of $10{ }^{\circ} \mathrm{C} / \mathrm{min}$, ending with $10 \mathrm{~min}$ at $280{ }^{\circ} \mathrm{C}$. The carrier gas (helium) had a flow rate of $1 \mathrm{~mL} / \mathrm{min}$, and the split mode had a ratio of $1: 20$. The injection port was set at $225^{\circ} \mathrm{C}$. The operating parameters for the quadrupole mass spectrometer were as follows: the interface temperature was set to $240{ }^{\circ} \mathrm{C}$ and the electron impact ionization to $70 \mathrm{eV}$, with a scan mass range of $40-350 \mathrm{~m} / \mathrm{z}$ at a sampling rate of $1 \mathrm{scan} / \mathrm{s}$. The components were identified by comparison of the retention indices of the components to those of $\mathrm{C}_{9}-\mathrm{C}_{28} \mathrm{n}$-alkanes and comparison of the mass spectra with literature data (Van Den Dool \& Kratz, 1963, Adams, 2007).

\section{Results}

\subsection{Anatomic study}

The foliar blade of $P$. guineense is hypoestomatic with paracytic and anisocytic (Figure 1A) stomata in paradermic section. The epidermis on both sides present cells with straight to slightly curved walls (Figure 1B). In the transversal section, it has uniestratified epidermis on the adaxial surface and hypodermis with two layers of cells, and uniestratified epidermis covered 
by thick cuticle on both sides (Figure 1D) and unicellular trichomes (Figure 1C). The mesophyll is dorsiventral, present palisade parenchyma with two cell layers, and lacunae parenchyma with four to five cell layers (Figure 1D). Secretory cavities are present in the lacunous parenchyma (Figure 1D). A vascular bundle with the extension of the sheath is observe (Figure 1D).

Figure 1 - A, B - Leaf blade Paradermic section. A- Paracytic (arrow) and anisocytic stomata (arrowhead) show in the abaxial face - B- Adaxial face. C-D - Transversal section of the mesophyll. C. unicellular trichomes. D. Secretory cavities are present in the lacunous parenchyma and cuticle on both sides (arrowhead). Be - Sclerenchymatous sheath. CS - Secretory cavity. Cu Cuticle. Ep - Epidermis. PL - Lacunous parenchyma. PP - Palisadic parenchyma.

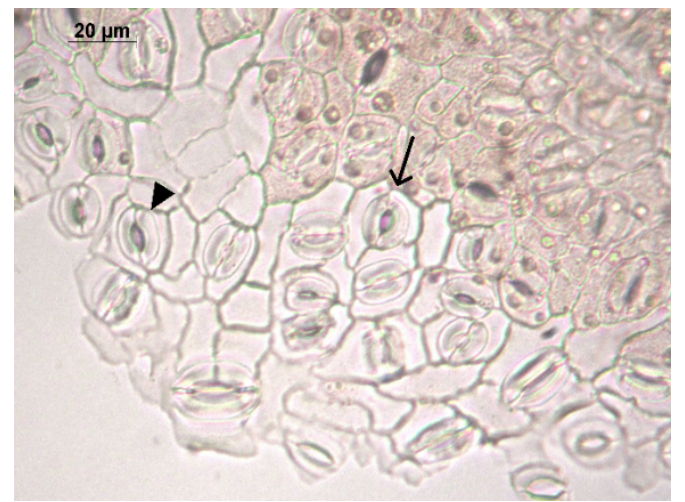

A

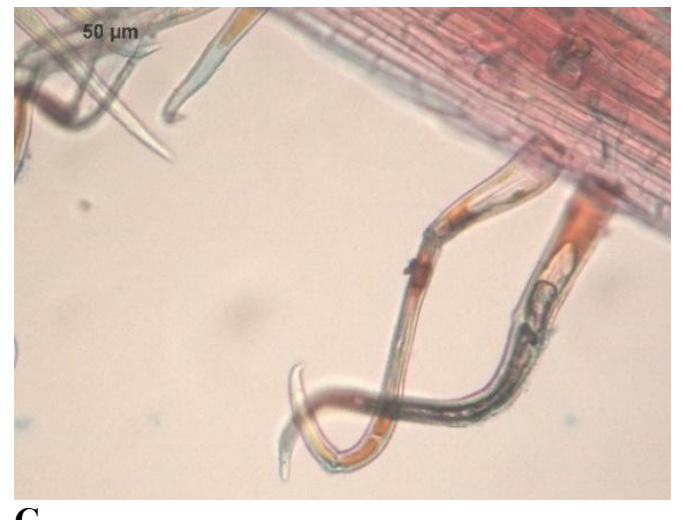

C

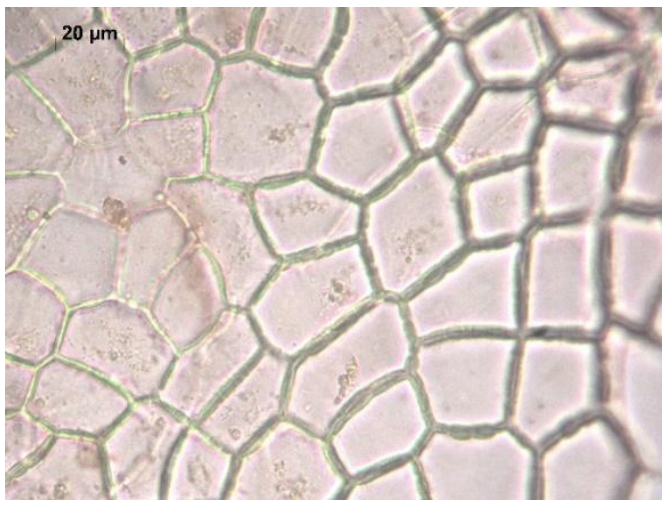

B

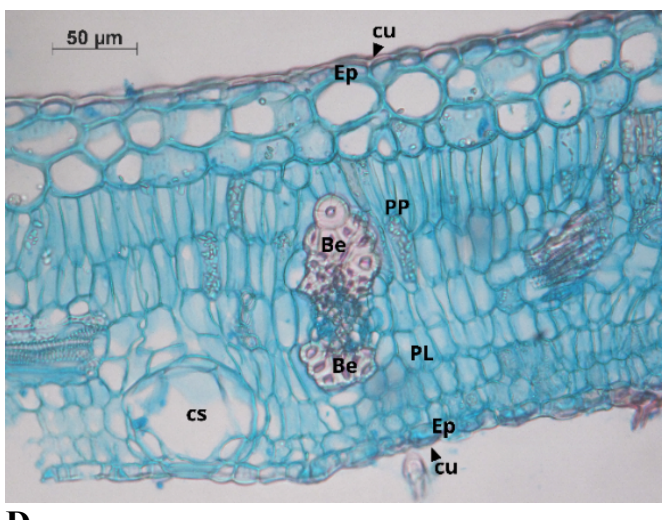

D

Source: Authors.

The main rib, in cross-section, has a plane-convex shape (Figure 2A). The epidermis is uniestratified coated by cuticle (Figure 2C), observing the presence of simple trichomes (Figure 2B). After the epidermis, there are about three to four layers of collenchyma cells (Figure 2D). The cortical parenchyma has from eight to ten layers of cells with secretory cavities (Figure 2F) and idioblasts containing druse-type crystals (Figure 2E). The vascular bundle is bicollateral with an arch shape surrounded by a range of sclerenchymatous sheath cells ranging from one to seven layers that emit projections between cells from the external and internal xylem to the phloem (Figure 2D). In the external phloem, idioblasts cells containing prismatic crystals are presented (Figure 2E). 
Figure 2 - A, B, C, D, E, F- Principal rib transverse sections. A- General aspect. B. Simple trichomes. C. Detail of the epidermis coated by cuticle, collenchyma and cortical parenchyma. D. Vascular bundle detail. E. Idioblast cells containing prismatic crystals. F. Cortical parenchyma with secretory cavity CS- Secretory cavity. CD - Crystal druse. CO - Collenchyma cells. CP - Polyhedral crystal. Cu - Cuticle. Ep - Epidermis. Es - Sclerenchymatous sheath. Fl - phloem. PC - Cortical Parenchyma Xi Xylem.

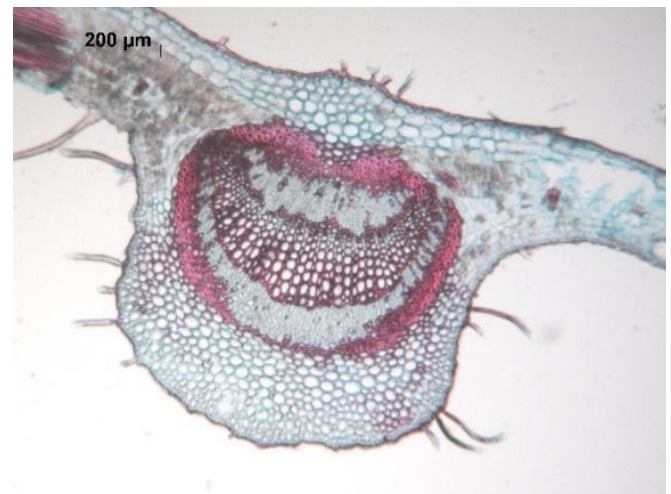

A
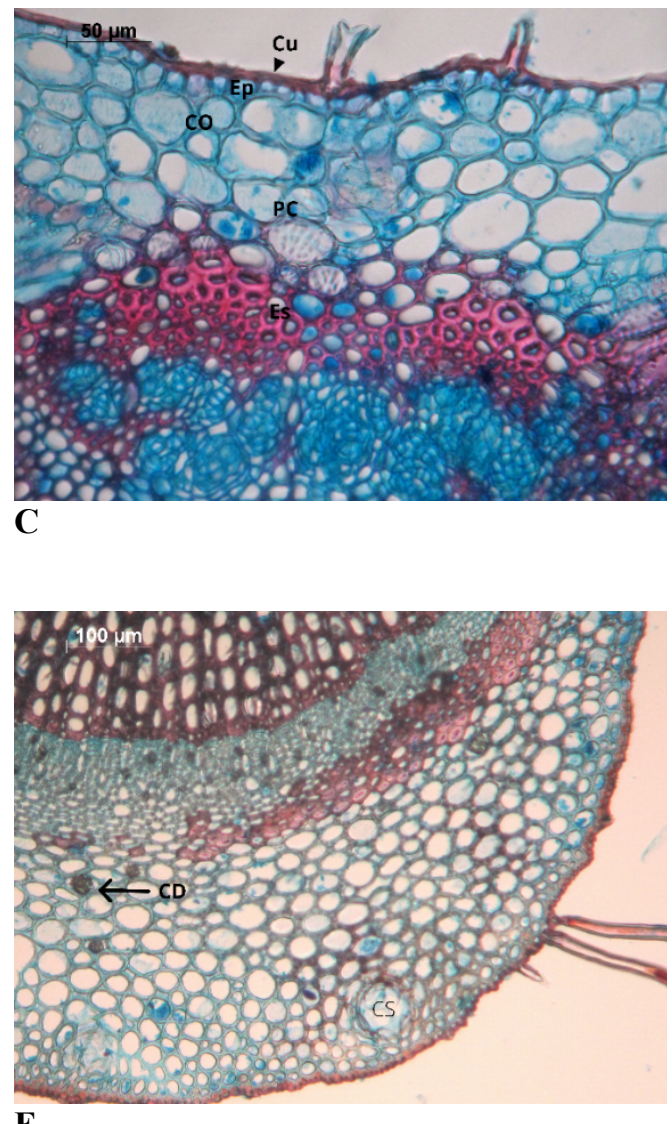

$\mathbf{E}$

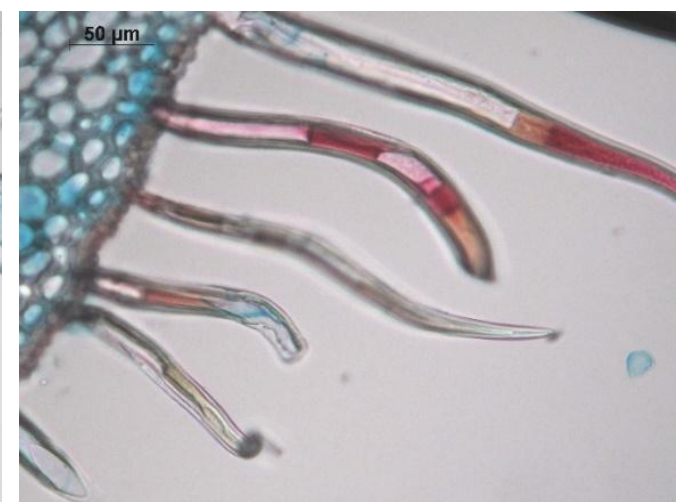

B

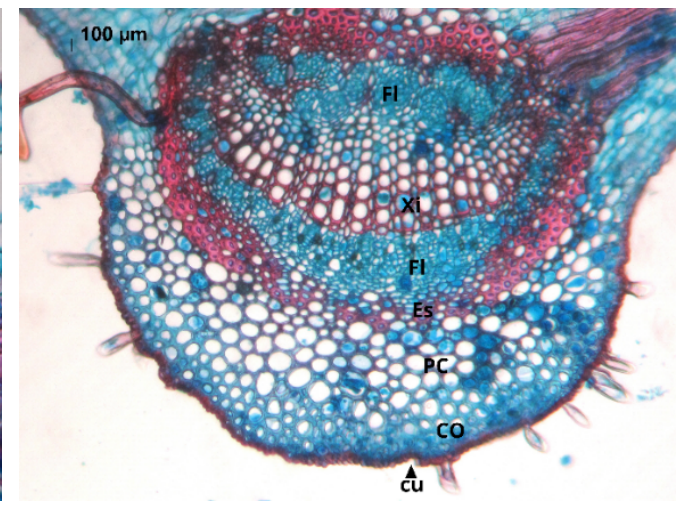

D

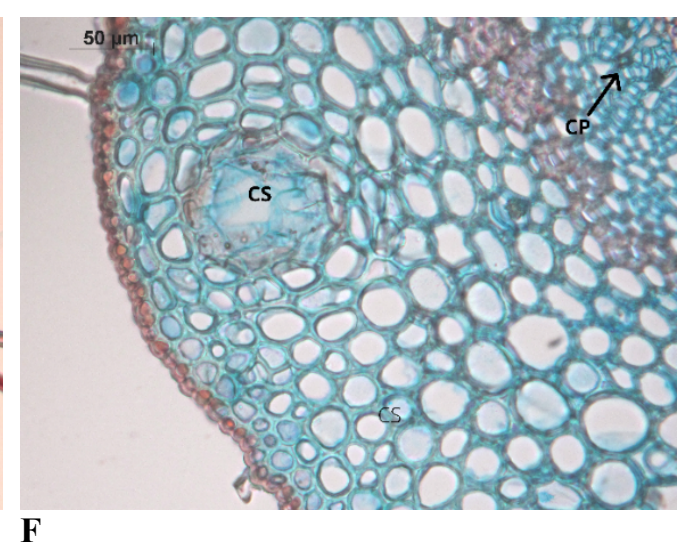

F

Source: Authors.

The petiole, in the transversal section, presents a plane-convex shape (Figure 3A) with uniestratified epidermis covered by a cuticle (Figure 3B and $3 \mathrm{~F}$ ). It presents a unicellular trichomas tectores. Below the epidermis, a collenchyma with three to four cell layers (Figure 3B) followed by cortical parenchyma with 10 to 12 cell layers, some presenting amyloplasts (Figure 3C). Secretory cavities (Figure 3B) and cells with points (Figure 3D) are observed in the cortical parenchyma. The vascular bundle is 
bicollateral with a revolute arch shape (Figure 3E). It presents medullary parenchyma with cells of different sizes. Druse-like crystals are observed in the cortical parenchyma and medullary parenchyma and prismatic crystals in the phloem (Figure 3E).

Figure 3 - A, B, C, D, E, F -Cross-sections of petiole. A. Overview of the petiole. B. Secretory cavities in the cortical parenchyma. C. Cortical parenchyma presenting amyloplasts. D. Secretory cavity, cells with points and druse-like crystals in the cortical parenchyma. E- Vascular bundle detail. F. Uniestratified epidermis covered by a cuticle (Steinmetz). A, B, C, D, EAlcian blue/safranin. Am - Amiloplasts. CS- Secretory cavity. CC - Collenchyma cells. Cr - Crystal. Cu - Cuticle. Ep Epidermis. Fl - Phloem. PC - Cortical parenchyma. Pm - Parenchyma medullary. Tr - Trichome Xi- Xylem.

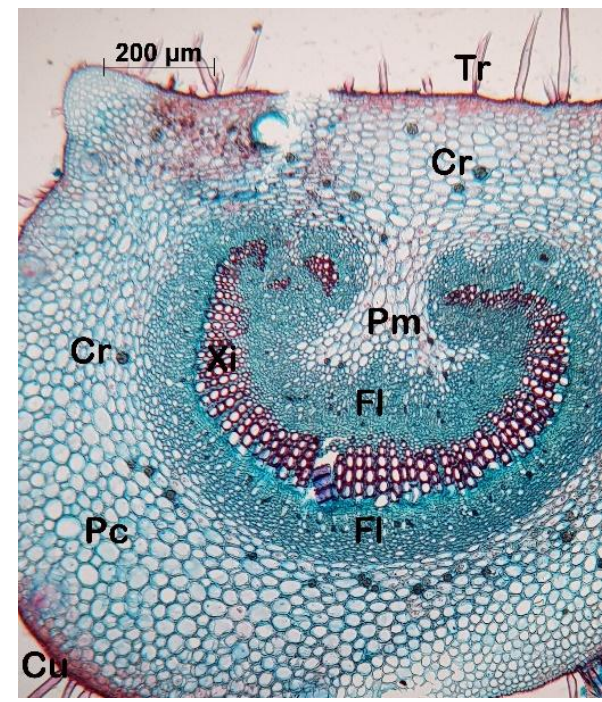

A

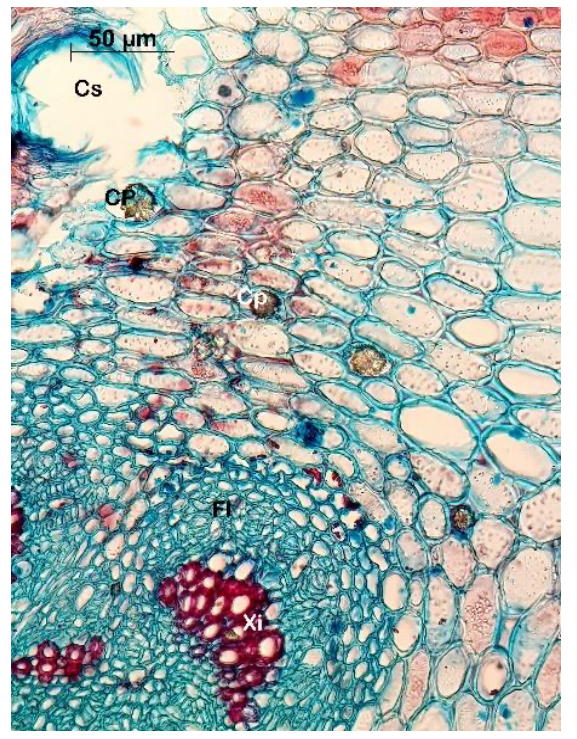

D

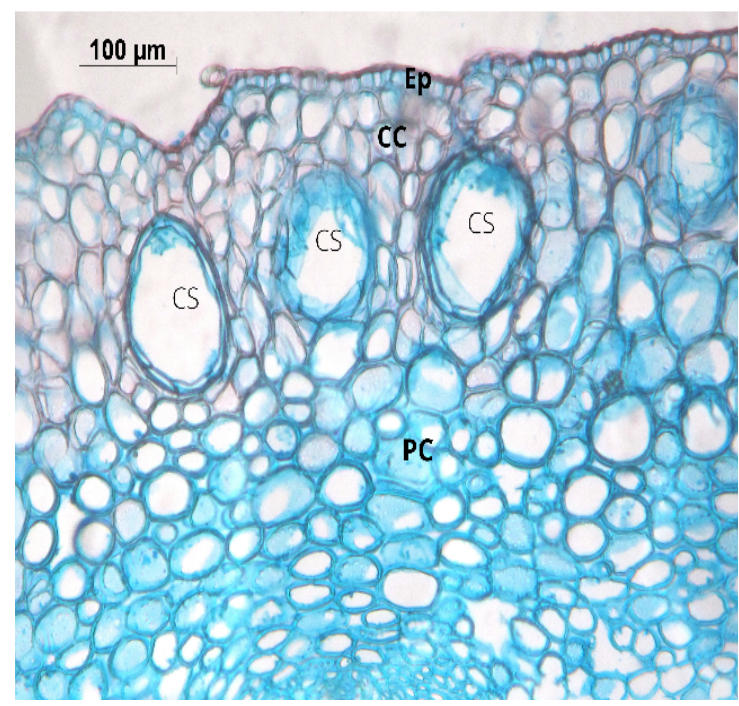

B

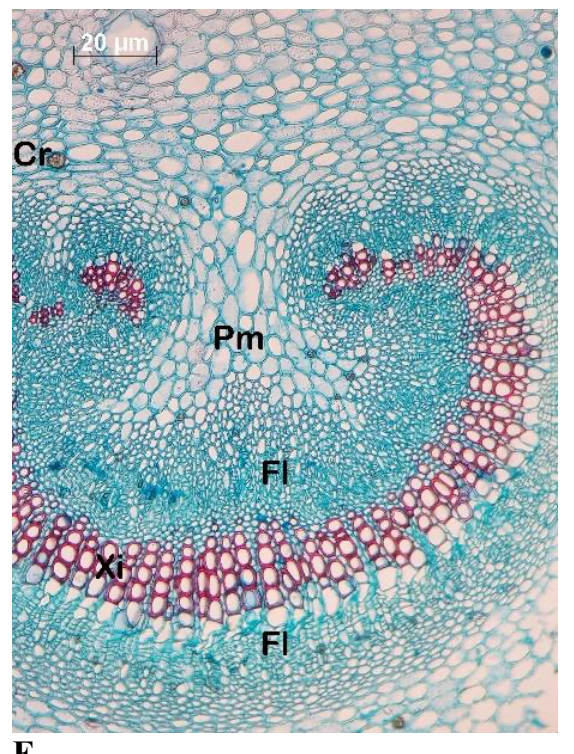

$\mathbf{E}$
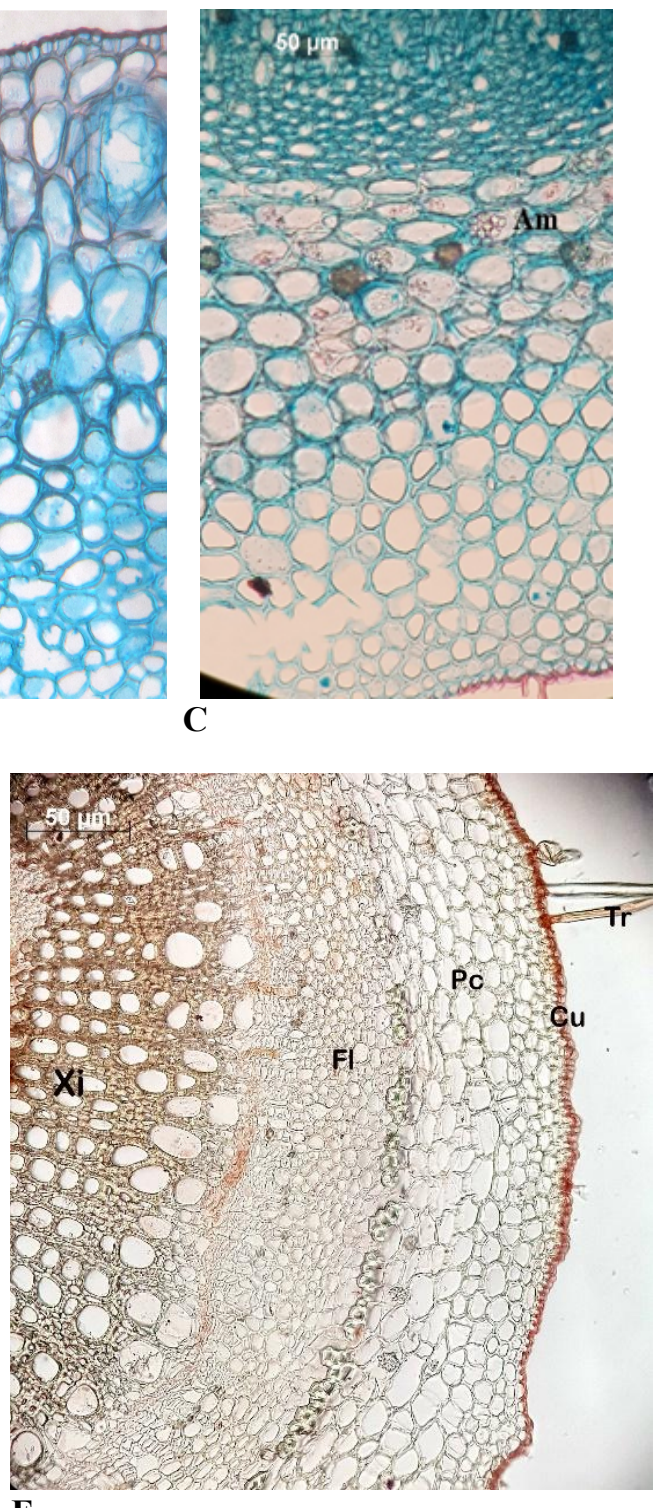

$\mathbf{F}$

Source: Authors.

The young stem, in cross-section, has an oval shape (Figure 4A) and is delimited by a uniestratified epidermis coated with cuticle (Figure 4B) and numerous unicellular trichomes (Figure 4C). The cortical parenchyma contains about eight to nine cell layers, presenting secretory cavities Figures 4B and 4C). In the vascular bundle a phloem is observed followed by medullary parenchyma with isodiametric cells of varying sizes. Presence of idioblasts containing druses in the cortical and medullary parenchyma and prismatic crystals in the phloem. 
Figure 4 - A. The general appearance of the young stem in the transversal section (polarized light), B, C, D, E Transversal sections of young stem. B. Secretory cavities in the cortical parenchyma C. Unicellular trichomes. D. Vascular bundle detail. CS- Secretory cavity. CD- Crystal drusa. Cp- Polyhedral crystal. Cr - Crystal. Cv- Vascular exchange. Ep - Epidermis. FlPhloem. Fv- Vascular bundle PC - Cortical parenchyma. Pm- Parenchyma medullary. Tr - Trichome. Xi - Xylem

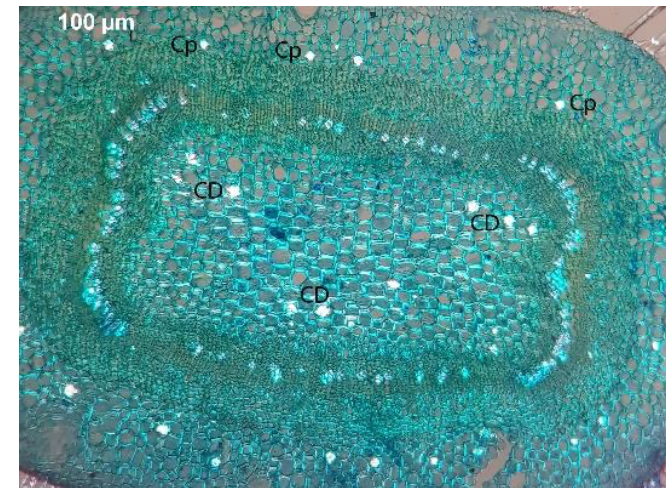

A

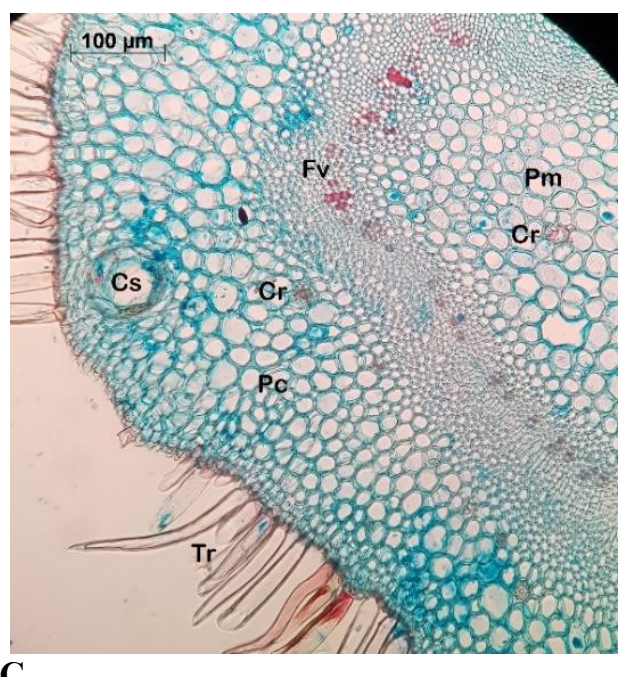

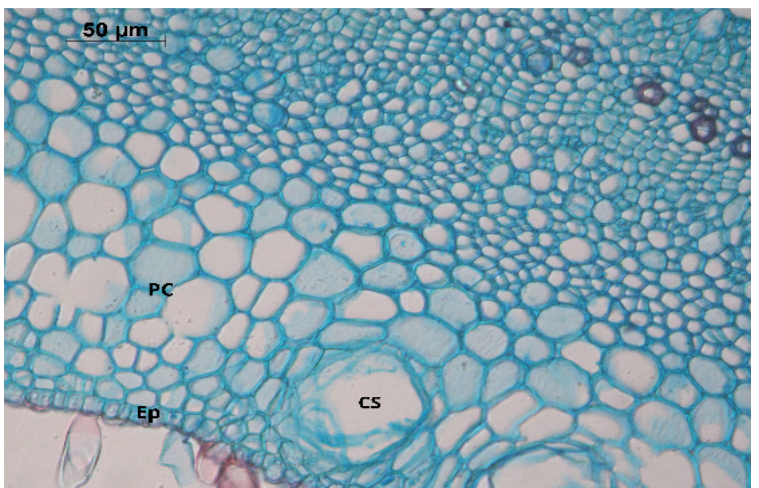

B

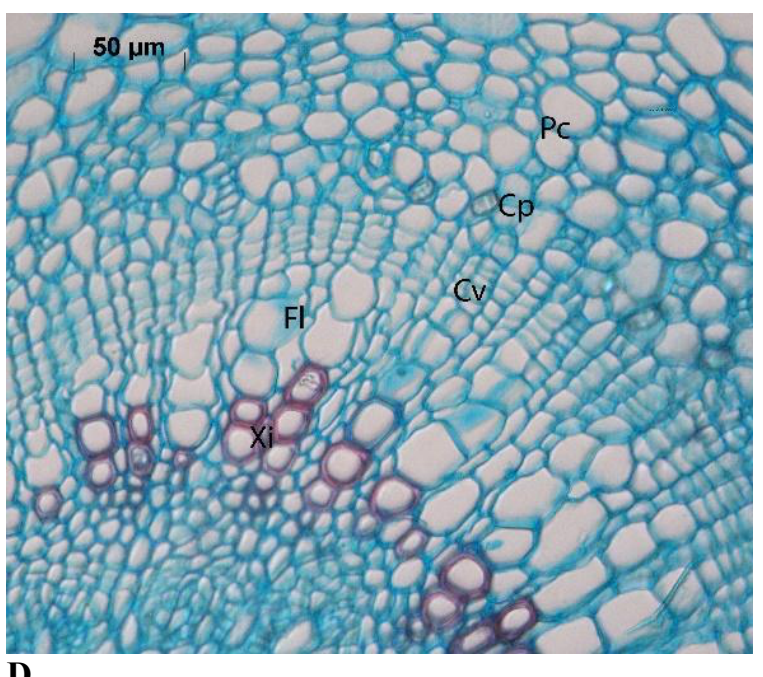

D

Source: Authors.

\subsection{Total ash content, acid-insoluble ash content, and phytochemical screening}

The powder moisture content was 7.4\%. The total ash content of the leaf powder was $6.3 \%$ and the acid-insoluble ash content was $0.8 \%$. The qualitative presence of tannins, flavonoids, and saponins in the leaves were identified.

\subsection{Volatile Oil}

The volatile oil yield from $P$. guineense leaves varied from 0.05 to $0.06 \%$ and 93.5 to $99.7 \%$ compounds were identified. The analysis resulted in the identification of 31 components (Table 1), which were $0.5 \%$ to $1.2 \%$ monoterpene hydrocarbons, $46.2 \%$ to $50.0 \%$ sesquiterpene hydrocarbons, $40,2 \%$ to $50.4 \%$ sesquiterpene oxygenates, $1.9 \%$ to $2.6 \%$ phenylpropanoids and $0 \%$ to $0.2 \%$ ketone. The major compounds were 2Z,6E-farnesol (23.1-25.4\%), $\alpha$-copaene (17.7-20.3\%) (Figure 5), muurola$4,10(1.4)$ dien-1- $\beta$-ol (5.8-6.7\%), and epi- $\alpha$-cadinol (5.5- 6.3\%).

For the fruits, the yield of volatile oil varied between $0.03-0.5 \%$. and 96.8 to $100 \%$ compounds. The analysis resulted in the identification of 34 components were identified, being $0 \%$ to $0.2 \%$ monoterpene hydrocarbons, $30.6 \%$ to $56.1 \%$ sesquiterpene hydrocarbons, $43.0 \%$ to $66.2 \%$ oxygenated sesquiterpenes and $0.4 \%$ to $1.0 \%$ phenylpropanoids. The major ones 
being 2Z,6E-farnesol (31.9-41.4\%), $\alpha$-copaene (13.3-26.6\%), $\delta$-cadinene (5.4-9.8\%), $\gamma$-himachalene $(3.8-6.1 \%)$, and cubenol (2.6-6.1\%) (Table 1).

Table 1 - Percentage of chemical compounds of volatile oils from Psidium guineense leaves and fruits collected in HidrolândiaGoiás, Brazil, in 2020.

\begin{tabular}{|c|c|c|c|c|c|c|c|c|c|c|}
\hline \multirow[b]{2}{*}{ Chemical compounds } & \multirow[b]{2}{*}{ KI } & \multirow[b]{2}{*}{ IR } & \multicolumn{2}{|c|}{ Leaves } & \multicolumn{2}{|c|}{ Green fruit } & \multicolumn{2}{|c|}{ Immature fruit } & \multicolumn{2}{|c|}{ Ripe fruit } \\
\hline & & & Jan & Feb & Jan & Feb & Jan & Feb & Jan & Feb \\
\hline Hepten-2-one 6-methyl- & & & & & & & & & & \\
\hline 5 & 985 & 984 & $0.2 *$ & 0 & 0 & 0 & 0 & 0 & 0 & 0 \\
\hline 1,8-Cineole & 1031 & 1028 & 1.2 & 0.5 & 0 & 0 & 0 & 0 & 0 & 0.2 \\
\hline 2-(1Z)-propenyl Phenol & 1150 & 1158 & 1.1 & 2.1 & 0.9 & 0.9 & 0.9 & 0.6 & 1.0 & 0.4 \\
\hline Hydrocinnamyl acetate & 1368 & 1367 & 0.8 & 0.5 & 0 & 0 & 0 & 0 & 0 & 0 \\
\hline$\alpha$-Copaene & 1376 & 1372 & 17.7 & 20.3 & 26.6 & 17.8 & 21.1 & 13.3 & 17.6 & 17.2 \\
\hline$\beta$-Funebrene & 1414 & 1415 & 2.3 & 1.8 & 1.5 & 0.9 & 1.5 & 0.6 & 1.7 & 1.0 \\
\hline$\alpha$-Humulene & 1454 & 1449 & 0.8 & 0.7 & 0.6 & 0 & 0.5 & 0.3 & 0.6 & 0.4 \\
\hline E- $\beta$-Farnesene & 1456 & 1456 & 0.7 & 0.6 & 0.6 & 0.5 & 0,6 & 0.7 & 0.7 & 0.7 \\
\hline 9-epi-E- Caryophyllene & 1466 & 1465 & 0 & 0 & 0 & 0 & 0 & 0.3 & 0 & 0.4 \\
\hline$\gamma$-Gurjunene & 1477 & 1472 & 1.0 & 1.4 & 1.0 & 0.9 & 0.9 & 0.8 & 0.8 & 1.0 \\
\hline$\gamma$-Himachalene & 1482 & 1484 & 4.9 & 5.1 & 6.1 & 4.7 & 4.9 & 3.8 & 4.0 & 4.5 \\
\hline$\beta$-Selinene & 1490 & 1490 & 4.1 & 4.3 & 5.8 & 4.3 & 4.5 & 3.6 & 3.8 & 4.2 \\
\hline$\alpha$-Muurolene & 1500 & 1497 & 1.7 & 2.1 & 1.8 & 1.3 & 1.6 & 0 & 1.5 & 1.5 \\
\hline$\beta$-Bisabolene & 1505 & 1506 & 0 & 0 & 0.6 & 0 & 0 & 0 & 0 & 0 \\
\hline$\alpha$-Cuprenene & 1505 & 1512 & 0 & 2.0 & 0 & 0 & 0 & 0 & 0 & 0 \\
\hline ס-Amorphene & 1512 & 1510 & 1.5 & 0 & 1.7 & 1.3 & 1.6 & 1.8 & 1.6 & 0 \\
\hline$\delta$-Cadinene & 1523 & 1520 & 5.0 & 5.9 & 9.8 & 6.6 & 8.2 & 5.4 & 6.0 & 6.1 \\
\hline Zonarene & 1529 & 1529 & 0 & 0.5 & 0 & 0 & 0 & 0 & 0 & 0 \\
\hline$\alpha$-Calacorene & 1545 & 1539 & 0.5 & 1.0 & 0 & 0 & 0 & 0 & 0.3 & 0.3 \\
\hline E-Nerolidol & 1563 & 1562 & 3.0 & 2.6 & 1.7 & 3.3 & 2.4 & 3.1 & 2.3 & 3.0 \\
\hline$\beta$-Copaen-4- $\alpha$-ol & 1590 & 1582 & 1.1 & 0.9 & 0 & 0 & 0 & 0.2 & 0 & 0 \\
\hline Carotol & 1599 & 1598 & 1.6 & 1.4 & 0 & 0 & 0 & 1.1 & 0.9 & 1.0 \\
\hline Globulol & 1587 & 1590 & 0 & 0 & 0 & 0 & 0 & 0.1 & 0 & 0 \\
\hline Ledol & 1602 & 1607 & 0.7 & 1.0 & 0 & 0 & 0 & 1.0 & 0.5 & 0.9 \\
\hline
\end{tabular}


Muurola-4,10(14)-dien-

\begin{tabular}{|c|c|c|c|c|c|c|c|c|c|}
\hline $1 \beta$-ol & 1631 & 1624 & 6.7 & 5.8 & 0 & 0 & 0 & 0 & 0 \\
\hline$\alpha$-Acorenol & 1631 & 1624 & 0 & 0 & 1.7 & 2.8 & 2.4 & 3.4 & 0 \\
\hline
\end{tabular}

Muurola-4,10(14)-dien-

$\begin{array}{ccccccccccc}\mathbf{1 - \beta - o l} & 1631 & 1624 & 0 & 0 & 0 & 0 & 0 & 0 & 3.6 & 3.4 \\ \text { Zonarene } & 1528 & 1529 & 0 & 0 & 0 & 0 & 0 & 0.3 & 0.3 & 0.4\end{array}$

Caryophylla-

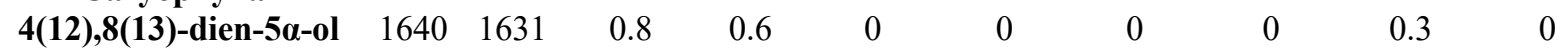

$\begin{array}{lllllllllll}\text { epi- } \alpha \text {-Cadinol } & 1640 & 1637 & 6.3 & 5.5 & 2.7 & 4.7 & 4.0 & 5.1 & 4.8 & 4.8\end{array}$

$\begin{array}{lllllllllll}\boldsymbol{\alpha} \text {-Muurolol } & 1646 & 1642 & 2.1 & 1.9 & 0.5 & 1.4 & 0.9 & 1.4 & 1.4 & 1.4\end{array}$

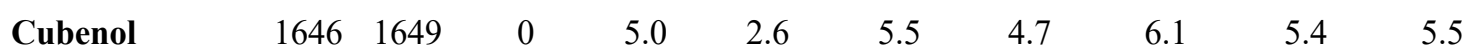

$\begin{array}{lllllllllll}\text { Cadalene } & 1676 & 1670 & 0 & 0.5 & 0 & 0 & 0 & 0 & 0 & 0\end{array}$

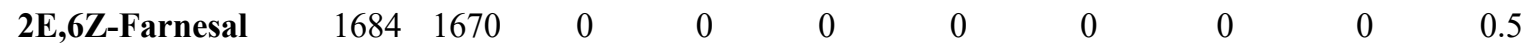

$\begin{array}{lllllllllll}\boldsymbol{\alpha} \text {-Bisabolol } & 1685 & 1682 & 0 & 0 & 0 & 0 & 0 & 0.3 & 0 & 0\end{array}$

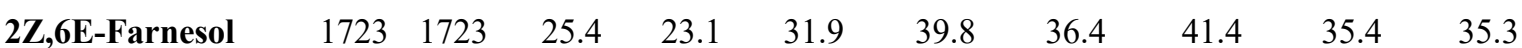

$\begin{array}{lllllllllll}\text { 2E,6E-Farnesal } & 1740 & 1741 & 0.4 & 0.4 & 0 & 0 & 0 & 0 & 0 & 0\end{array}$

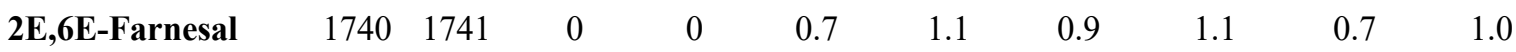

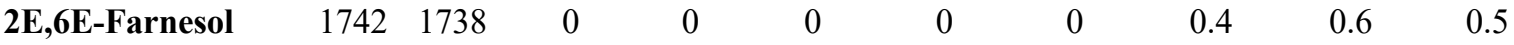

$\begin{array}{llllllllll}\boldsymbol{\beta} \text {-Bisabolenal } & 1767 & 1769 & 0.8 & 0.9 & 0 & 0 & 0 & 0 & 0\end{array}$

2E,6E-Methyl

$\begin{array}{lllllllllll}\text { farnesoate } & 1784 & 1783 & 0 & 0 & 0 & 0 & 0 & 0.2 & 0 & 0\end{array}$

$\begin{array}{lllllllllll}\text { 2Z,6E-Farnesyl acetate } & 1846 & 1841 & 1.1 & 1.3 & 1.2 & 1.1 & 1.3 & 1.0 & 1.6 & 1.2\end{array}$

$\begin{array}{lllllllll}\text { Ketone } & 0.2 & 0 & 0 & 0 & 0 & 0 & 0 & 0\end{array}$

Phenylpropanoid

$\begin{array}{llllllll}1.9 & 2.6 & 0.9 & 0.9 & 0.9 & 0.6 & 1.0 & 0.4\end{array}$

\begin{tabular}{ccccccccc}
$\begin{array}{c}\text { Sesquitepene } \\
\text { hydrocarbons }\end{array}$ & 50.0 & 46.2 & 56.1 & 38.3 & 45.4 & 30.6 & 38.6 & 37.3 \\
\hline $\begin{array}{c}\text { Oxygenated } \\
\text { sesquiterpenes }\end{array}$ & 40.2 & 50.4 & 43.0 & 59.7 & 53.0 & 66.2 & 57.8 & 58.9 \\
\hline $\begin{array}{c}\text { Hydrocarbon } \\
\text { Monoterpenes }\end{array}$ & 1.2 & 0.5 & 0 & 0 & 0 & 0 & 0 & 0.2 \\
\hline $\begin{array}{c}\text { Total } \\
\text { identified (\%) }\end{array}$ & 93.5 & 99.7 & 100.0 & 98.9 & 99.3 & 97.4 & 97.4 & 96.8 \\
\hline Yield (\%) & 0.05 & 0.06 & 0.04 & 0.04 & 0.03 & 0.03 & 0.5 & 0.16 \\
\hline
\end{tabular}

KI: Kovax index; RI: retention index; Jan: January; Feb: February; $*$ all the number of the constituents are expressed in percentage.

Source: Authors. 
Figure 5 - Chemical structure of the major components of Psidium guineense volatile oil leaves A. 2Z,6E Farnesol. B. $\alpha$ Copaene.

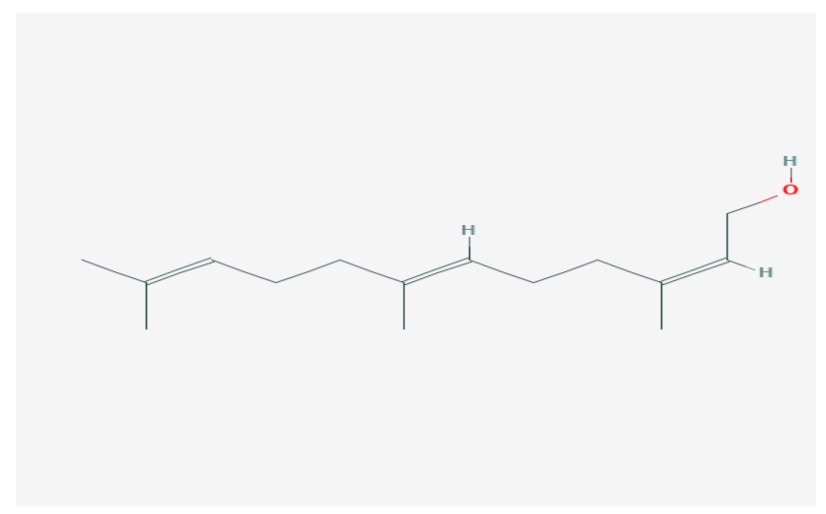

A

Source: Pubchem (2021a, b).

\section{Discussion}

In the present study, uniestratified adaxial epidermis with double layer of hypodermis, palisadic parenchyma with 2 layers of cells, numerous unicellular trichomes, paracytic, and anisocytic stomata were observed while Silva, et al. (2007) observed only paracytic stomata in the abaxial epidermis of $P$. guineense and only one layer of cells in the palisadic parenchyma. According to Brewer, et al. (1991), the trichomes may be responsible for water retention on the leaf surface by retaining water droplets, improving the photosynthetic process by allowing greater opening of the stomata. Secretory cavities containing volatile oils and crystals in forms of druses described in the leaves and young stem in this study were also described by Oliveira (2015), being a common feature of Myrtaceae species (Metcalfe \& Chalk 1979).

The determination of moisture in herbal drugs is important in quality evaluation. Water excess produces unwanted chemical reactions and microbial contamination. Total ash and acid-insoluble ash in high levels indicates impurities like nonorganic materials and silica (Alves, et al., 2010; Brasil, 2019). Official compendia have not established parameters for $P$. guineense. However, limit values for moisture are $12.0 \%$ and total ash $9.0 \%$ for P. guajava powder (Brasil, 2019). P. guineense powder of the leaves displayed values of $7.4 \%$ moisture, $6.3 \%$ total ash, and $0.8 \%$ acid-insoluble ash. Tannins, flavonoids, and saponins were also identified in the leaves. These compounds were also described in the methanolic extract of $P$. guineense leaves from India by Sruthi, et al. (2019), alongside coumarins, terpenoids, and quinones.

The majority of compounds in volatile oil from $P$. guineense leaves were 2Z,6E-farnesol, $\alpha$-copaene, muurola$4,10(1,4)$, dien-1- $\beta$-ol, cubenol, epi- $\alpha$-cadinol, $\delta$-cadinene, and $\gamma$-himachalene, whereas for the fruits were 2 Z,6E-farnesol, $\alpha$ copaene, $\beta$-bisabolene, $\delta$-cadinene, $\beta$-amorphene, cubenol, and epi- $\alpha$-cadinol. However, Figueiredo, et al. (2018) identified $\alpha$ pinene, $\alpha$-copaene, and E-caryophyllene as major components in the leaf volatile oils collected in Pará, while Silva, et al. (2003) identified $\beta$-bisabolol, limonene, and epi- $\alpha$-bisabolol from leaves collected in Roraima State.

In volatile oil from P. guineense leaves collected in Ceará State, Brazil, Neto, et al. (1994) found as major components 1.8-cineole (40.5\%), $\beta$-eudesmol (19.5\%) and $\alpha$-pinene (13.9\%). Tucker et al. (1995) determined as the main components of the leaves volatile oil in Mexico, $\beta$-bisabolene (13.18\%), $\alpha$-pinene (12.85\%) and Z-nerolidol (5.50\%). Spathulenol (80.71\%) was the main component of the volatile oil, followed by 2Z,6E-farnesol (3.65\%) and $\gamma$-terpineol (1.91\%) in Mato Grosso do Sul (Nascimento, et al., 2018). Peralta-Bohórquezo (2011), in Mexico, identified in the fruits volatile oil the components ethyl butyrate $(30.3 \%)$, ethyl hexanoate $(23.8 \%), \beta$-caryophyllene $(3.3 \%)$ by headspace solid phase extraction and $\beta$-caryophyllene $(8.6 \%)$, while butanol (7.4\%) and ethyl butyrate (7.4\%) when obtained by distillation extraction. 
2Z,6E-farnesol belongs to the class of organic compounds known as sesquiterpenoids. These terpenes are constructed by three consecutive isoprene units (HMDB, 2021). Su, et. al. (2015) described the antimicrobial activity of 2Z-6E farnesol by microdilution broth method using minimum inhibitory concentration against Aspergillus niger $(500 \mu \mathrm{g} / \mathrm{mL})$, Bacillus cereus $(62.25 \mu \mathrm{g} / \mathrm{mL})$, Candida albicans $(31.25 \mu \mathrm{g} / \mathrm{mL})$, Enterobacter aerogenes $(62.25 \mu \mathrm{g} / \mathrm{mL})$, Escherichia coli $(62.5 \mu \mathrm{g} / \mathrm{mL})$, Klebsiella pneumoniae $(125 \mu \mathrm{g} / \mathrm{mL})$, Pseudomonas aeruginosa $(125 \mu \mathrm{g} / \mathrm{mL})$, Staphylococcus aureus $(31.25 \mu \mathrm{g} / \mathrm{mL}), S$. epidermidis $(31.25 \mu \mathrm{g} / \mathrm{mL})$, and Vibrio parahaemolyticus $(500 \mu \mathrm{g} / \mathrm{mL})$. The anticancer potential was tested on three human cancer cell lines: HT-29 (human colon), J5 (human hepatocellular carcinoma), and A549 (human lung adenocarcinoma). 2Z-6E farnesol reduced the viability $50 \%$ of HT-29, J5, and A549 cells at 10.6, 36.8, and $26.8 \mu \mathrm{g} / \mathrm{mL}$, respectively.

$\alpha$-Copaene belongs to the sesquiterpenoid class (HMDB, 2021b). Rodrigues, et al. (2018) observed antileishmanial activity of $\alpha$-copaene in vitro, reducing viability by $50 \%$ for Leishmania amazonensis and L. infantum at the concentration of 17.2 and $11.4 \mu \mathrm{g} / \mathrm{mL}$, respectively.

The chemical composition of the volatile oil of $P$. guineense showed component variation due to the studies being made in different regions, with different temperatures, pluviometric indexes, altitudes, type of soil, and incidence of ultraviolet rays (Gobbo-Neto \& Lopes, 2007). According to Sangwan, et al. (2001) the volatile oils production depends on physiological, biochemical, metabolic and genetic aspects of the plant, and may suffer environmental and molecular modulations elucidating the chemical variations of volatile oils.

Due to the small size of the fruit, the amount of volatile oil obtained was low, a fact that represented a limitation of the study.

\section{Conclusion}

Anatomical studies, moisture content and total and insoluble ash in this study contribute to the quality control of plant raw material. Phytochemical screening is important to observe classes of molecules with possible biological activity. In this context qualitative presence of tannins, flavonoids, and saponins in the leaves were observed.

Leaves and fruits volatile oil's majority compounds were 2Z,6E-farnesol and $\alpha$-copaene. This is the first report on anatomical study of the leaves, and chemical composition of volatile oils from P. guineense leaves and fruits collected in Hidrolândia, Goiás.

\section{Acknowledgments}

The authors gratefully acknowledge the financial support of the Coordenação de Aperfeiçoamento de Pessoal de Nível Superior - Brasil (CAPES), the Conselho Nacional de Desenvolvimento Científico e Tecnológico (CNPq), and the Fundação de Amparo à Pesquisa do Estado de Goiás (FAPEG). This study was financed in part by the CAPES, Finance Code 001.

\section{References}

Adams, R. P. (2007). Identification of essential oil components by Gas Chromatography/Mass Spectroscopy (4a ed.). Carol Stream, IL: Allured Publ. Corp.

Alves, M. S. M., Mendes, P. C., Vieira, J. G. P., Ozela, E. F., Barbosa, W. L. R., \& Júnior, J. O. C. S. (2010). Análise farmacognóstica das folhas de Arrabidaea chica (Humb. \& Bonpl.) B. Verlt., Bignoniaceae. Revista Brasileira de Farmacognosia, 20 (2), 215-221. https://doi.org/10.1590/S0102-695X2010000200013

Brasil (2010). Farmacopéia Brasileira (5a ed.). Atheneu.

Brasil (2019). Farmacopeia Brasileira (6a ed.). Agência Nacional de Vigilância Sanitária.

Brewer, C. A., Smith, W. K., \& Vogelmann, T. C. (1991). Functional interaction between leaf trichomes, leaf wettability and the optical properties of water. Plant, Cell \& Environment, 14, 955-962. https://doi.org/10.1111/j.1365-3040.1991.tb00965.x

Costa, A. F. (2001). Farmacognosia: Farmacognosia Experimental (3a ed.). Lisboa: Fundação Calouste Gulbenkian. 
Coutinho, L. M. (2006). O conceito de bioma. Acta Botanica Brasilica, 20 (1), 13-23. https://doi.org/10.1590/S0102-33062006000100002

Cunha, A. P. (2009). Farmacognosia e Fitoquímica (2a ed.). Fundação Calouste Gulbenkian.

Figueiredo, P. L. B., Silva, R. C., Silva, J. K. R., Suemitsu, C., Mourão, R. H. V., \& Maia, J. G. S. (2018). Chemical variability in the essential oil of leaves of araçá (Psidium guineense Sw.), with occurrence in the Amazon. Chemistry Central Journal, 12 (52), 1-11. https://doi.org/10.1186/s13065-018-0428-z

Forzza, R. C., Baumgratz, J. F. A., Bicudo, C. E. M., Canhos, D. A. L., Carvalho Jr., A. A., Coelho, M. A. N., Costa, A. F., Costa, D. P., Hopkins, M. G., Leitman, P. M., Lohmann, L. G., Lughadha, E. N., Maia, L. C., Martinelli, G., Menezes, M., Morim, M. P., Peixoto, A. L., Pirani, J. R., Prado, J., Queiroz, L. P., Souza, S., Souza, V. C., Stehmann, J. R., Sylvestre, L. S., Walter, B. M. T., \& Zappi, D. C. (2012). New Brazilian floristic list highlights conservation challenges. Bioscience, 62, 39-45. https://doi.org/10.1525/bio.2012.62.1.8

Gobbo-Neto, L., \& Lopes, N. P. (2007) Plantas medicinais: fatores de influência no conteúdo de metabólitos secundários. Química Nova, 30 (2), 374-381. https://doi.org/10.1590/S0100-40422007000200026

González, A. M. N., González, M. B. R., \& Pinto, N. L. S. (2005). Estudio fitoquímico y actividad antibacterial de Psidium guineense Sw (choba) frente a Streptococcus mutans, agente causal de caries dentales. Revista Cubana de Plantas Medicinales, 1, 3-4.

HMDB (2021a). Human Metabolome Database. https://hmdb.ca/metabolites/HMDB0059849

HMDB (2021b). Human Metabolome Database. https://hmdb.ca/metabolites/HMDB0061851

Kraus, J. E., \& Arduin, M. (1997). Manual básico de métodos em morfologia vegetal. Rio de Janeiro: Editora da Universidade Federal Rural do Rio de Janeiro.

Manica, I. (2000). Frutas nativas, silvestres e exóticas 1 - Técnicas de produção e mercado: abiu, amora-preta, araça, bacuri, biriba, carambola, cereja-dorio-grande, jabuticaba. Porto Alegre: Cinco Continentes.

Metcalfe, C. R., \& Chalk, L. (1979). Anatomy of dicotyledons (2a ed.). Claredon Press.

Nascimento, K. F., Moreira F. M. F., Santos, J. Á., Kassuya, C. A. L., Croda, J. H. R., Cardoso, C. A. L., Vieira, M. C., Foglio, M. A., Carvalho, J. E., \& Formagio, A. S. N. (2018). Antioxidant, anti-inflammatory, antiproliferative and antimycobacterial activities of the essential oil of Psidium guineense Sw. and spathulenol. Journal of Ethnopharmacology, 210, 351-358. https://doi.org/10.1016/j.jep.2017.08.030

Neto, M. A., Alencar, J. W., Cunha, A. N., Silveira, E. R., \& Batista, T. G. (1994). Volatile constituents of Psidium pohlianum Berg. and Psidium guyanensis Pers. Journal of Essential Oil Research, 6, 299-300. https://doi.org/10.1080/10412905.1994.9698379

Novaes, P., Molinillo, J. M. G., Varela, R. M., \& Macías, F. A. (2013). Ecological phytochemistry of Cerrado (Brazilian savanna) plants. Phytochemistry Reviews, 12, 839-855. https://doi.org/10.1007/s11101-013-9315-3

Oliveira, E. F. (2015). Morfoanatomia e micromorfologia comparada das folhas de espécies de Psidium L. (Myrtaceae) do cerrado goiano. Dissertation, Universidade Estadual de Goiás.

Oliveira, R. F., Mendes, V. D., Molina, S., \& Clemente, E, (2014). Study Post -Harvest about impact and compression mechanical in the cell quality of guava fruit (CV. Paluma). International Journal of Science, 3(8), 30-34.

Peixoto, A. L., Carrijo, T.T. \& Tuler, A. C. (2017). Revisitando a flora de Macaé de Cima, Rio de Janeiro, Brasil: o gênero Psidium (Myrtaceae), São Paulo, Brasil. Rodriguésia, 61, 1323-1331. https://doi.org/10.1590/2175-7860201768414

Peralta-Bohórquezo, A. F., Parada, F., Quijano, C. E., \& Pino, J. A. (2010). Analysis of volatile compounds of sour guava (Psidium guineense Swartz) fruit. Journa of Essent Oil Reseach, 22 (6), 493-498. https://doi.org/10.1080/10412905.2010.9700381

Pubchem (2021a). Compound summary Alpha Copaene. https://pubchem.ncbi.nlm.nih.gov/compound/19725

Pubchem (2021b). Compound summary (2Z,6E)-Farnesol. https://pubchem.ncbi.nlm.nih.gov/compound/1549108

Rodrigues, V. E. G., \& Carvalho, D. A. (2001). Plantas medicinais no domínio dos cerrados. UFLA.

Rodrigues, I. A., Ramos, A. S., Falcão, D. Q., Ferreira, J. L. P., Basso, S. L., Silva, J. R. A. \& Amaral, A.C.F. (2018). Development of nanoemulsions to enhance the antileishmanial activity of Copaifera paupera oleoresins. BioMed Research International, 9, 1-9. https://doi.org/10.1155/2018/9781724

Sangwan, N. S., Farooqi, A. H. A., Shabih, F. \& Sangwan, R. S. (2001). Regulation of essential oil production in plant. Plant Growth Regulation, 34, 3-21. https://doi.org/10.1023/A:1013386921596

Santos, E., Radai, J. A. S., Nascimento, K. F., Formagio, A. S. N., Balsalobre, N. M., Ziff, E. B., Konkiewitz, E. C., \& Kassuya, C. A. L. (2020). Contribution of spathulenol to the anti-nociceptive effects of Psidium guineense. Nutritional Neuroscience, 11, 1-11. https://doi.org/10.1080/1028415X.2020.1815330

Santos, F. A., Rao, V. S. N., \& Silveira, E. R. (1996). Studies on the neuropharmacological effects of Psidium guyanensis and Psidium pohlianum essential oils. Phytotherapy Research, 10, 655-658. https://doi.org/10.1002/(SICI)1099-1573(199612)10:83.0.CO;2-X

Santos, F. A., Rao, V. S. N., \& Silveira, E. R. (1997). The leaf essential oil of Psidium guyanensis offers protection against pentylenetetrazole-induced seizures. Planta Medica, 63 (2):133-135. https://doi.org/10.1055/s-2006-957629

São Paulo (1978). Secretaria da Agricultura. Coordenadoria da Pesquisa Agropecuária. Instituto de Tecnologia de Alimentos. Frutas tropicais: goiaba: da cultura ao processamento e comercialização. Campinas.

Silva, A. T., \& Mazine, F. F. (2016). A família Myrtaceae na Floresta Nacional de Ipanema, Iperó, 583 São Paulo, Brasil. Rodriguésia, 67(1), 203-223. https://doi.org/10.1590/2175-7860201667110 
Research, Society and Development, v. 10, n. 6, e49110615929, 2021

(CC BY 4.0) | ISSN 2525-3409 | DOI: http://dx.doi.org/10.33448/rsd-v10i6.15929

Silva, J. D., Luz, A. I. R., Silva, M. H. L., Andrade, E. H. A., Zoghbi, M. G. B., \& Maia, J. G. S. (2003). Essential oils of the leaves and stems of four Psidium spp. Flavour and Fragrance Journal, 18, 240-243. https://doi.org/10.1002/ffj.1219

Silva, L. C., Freitas-Silva, L., Rocha, D. I., Pereira, J. S. C., \& Assis, D. E. F. (2020). Leaf morpho-anatomical structure determines differential response among restinga species exposed to emissions from an iron ore pelletizing plant. Water, Air, \& Soil Pollution, 231 (152), 1-9. https://doi.org/10.1007/s11270-020-04533$\mathrm{x}$

Silva, M. D., Chagas, M. G. S., \& Pimentel, R. M. M. (2007). Anatomia foliar de espécies lenhosas dominantes numa área de restinga. Revista Brasileira de Biociências, 5 (1), 543-545.

Sruthi, C. P., Arathi, S. V., Joseph, J., \& Thomas, B. (2019). Phytochemical screening of leaf extracts of Psidium guajava and Psidium guineense (Myrtaceae). International Journal of Research and Analytical Reviews (IJRAR), 6 (1), 37-42. https://doi.org/10.30574/gscbps.2017.1.2.0024

Su, Y., Hsu, K., Wang, E. I., \& Ho, C. (2015). Composition, in vitro cytotoxic and antimicrobial activities of the flower essential oil of Diospyros discolor from Taiwan. Natural Product Communications, 10 (7), 1311-1314. https://doi.org/10.1177/1934578X1501000744

Tucker, A. O., Maciarello, \& M. J., Landrum, L. R. (1995). Volatile leaf oils of american Myrtaceae. III. Psidium cattleianum Sabine, P. friedrichsthalianum (Berg) Niedenzu, P. guajava L., P. guineense Sw., and P. sartorianum (Berg) Niedenzu. Journal of Essential Oil Research, 7 (2), 187-190. https://doi.org/10.1080/10412905.1995.9698497

Van Den Dool, H., \& Kratz, P. D. (1963). A generalization of the Retention Index system including linear temperature programmed gas - liquid partition chromatography. Journal of Chromatography, 11, 463-471. https://doi.org/10.1016/S0021-9673(01)80947-X 